\title{
Twenty-five milligrams of clomiphene citrate presents positive effect on treatment of male testosterone deficiency - a prospective study
}

\author{
Carlos Teodósio Da Ros, Márcio Augusto Averbeck \\ Centro de Andrologia e Urologia, Porto Alegre, Brazil
}

\section{ABSTRACT}

Introduction: Male testosterone deficiency is associated with bad sexual function and quality of life $(\mathrm{QoL})$. The aim of this study was to determine whether a daily dose of $25 \mathrm{mg}$ clomiphene citrate (CC) is effective in stimulating the endogenous testosterone production pathway and to address the applicability of this medication as a therapeutic option for symptomatic hypogonadism.

Materials and Methods: This was a prospective study. Men with low sexual desire and testosterone levels (T) below $400 \mathrm{ng} / \mathrm{dL}$ were selected to receive CC. Blood samples were obtained to determine baseline measurements of serum T, estradiol, LH, lipid profile and fasting plasma glucose. Each patient was treated with a daily dose of $25 \mathrm{mg}$ CC for at least 3 months. Patients were asked if they experienced any side effects related to the use of CC and if they experienced any improvement in their sexual profile. Paired samples T-test was utilized to analyze responses to therapy.

Results: Our cohort consisted of 125 men with hypogonadism and low libido. Mean age was 62 years $( \pm 11.1$ years). Serum T levels ranged from $309 \mathrm{ng} / \mathrm{dL}$ (baseline, mean value) to $642 \mathrm{ng} / \mathrm{dL}$ ( 3 months after CC initiation, mean value) ( $\mathrm{p}<0.001)$. Serum cholesterol levels ranged from 197 to $186 \mathrm{mg} / \mathrm{dL}(\mathrm{p}=0.003)$. There were no statistically significant differences when comparing pre and post-treatment HDL-Cholesterol, triglycerides, fasting plasma glucose and prolactin. All men reported improvements in the post-treatment QoL scores. No serious adverse events were recorded.

Conclusions: The CC was effective in stimulating the endogenous production of testosterone. A lower level of total cholesterol was verified after three months of treatment. This medication should be considered as a therapeutic option for some patients with symptomatic male testosterone deficiency.
ARTICLE INFO

\section{Key words:}

Hypogonadism; Clomiphene;

Treatment Outcome

Int Braz J Urol. 2012; 38: 512-18

\section{Submitted for publication:}

March 21, 2011

Accepted after revision: June 21, 2012

\section{INTRODUCTION}

Male testosterone deficiency is a syndrome associated with hormonal profile changes which negatively affects libido, sexual function, mood, behavior, lean body mass, and bone density (1). Actually, testosterone deficiency has been implicated with decline of the quality of the erections, loss of libido, osteoporosis, weight gain, muscle weakness, decreased lean body mass, diabetes mellitus and cognitive changes (2). The decrease in serum testosterone (T) may be due to primary testicular failure (3) and/or dysfunction of the hypothalamic-pituitary axis (4). This deficiency in aging males is associated with increased 
body weight, adipose tissue, and estrogens, due to peripheral conversion of $\mathrm{T}$ to estradiol (5). The negative feedback mechanism from excess estradiol results in a paradoxically low LH (luteinizing hormone) secretion from the pituitary despite a physiologically low T level (1).

Currently, the most common treatment of symptomatic male testosterone deficiency is $\mathrm{T}$ therapy with various transdermal, oral and injectable delivery methods. The main purpose of the $\mathrm{T}$ replacement is to achieve normal range in $\mathrm{T}$ serum levels and to get the positive effect over the complaints. However, this treatment can be associated with skin irritation, gynecomastia, nipple tenderness, testicular atrophy and decline in sperm counts (5). T replacement causes suppression of the hypothalamic-pituitary-gonadal axis via a negative feedback mechanism $(1,6)$. Low levels of gonadotropin releasing hormone (GnRH), in turn, further decrease production of luteinizing hormone (LH) and follicle stimulating hormone (FSH) by the pituitary gland. The low LH levels translate to low $\mathrm{T}$ production by the Leydig cells in the testes. The reduction in FSH could result in suppression of spermatogenesis (1).

Physiologic inhibition of pituitary gonadotropin secretion in men by $\mathrm{T}$ is mainly mediated by aromatization to estrogen, which inhibits hypothalamic secretion of GnRH. Clomiphene citrate is a weak estrogen receptor antagonist and thus may be considered a selective estrogen receptor modulator. It competes with estradiol for the estrogen receptors at the level of the hypothalamus and blocks the normal negative feedback mechanism of circulating estradiol on the hypothalamus, preventing estrogen from limiting the production of GnRH. The increase in GnRH level then stimulates the pituitary gland to release more FSH and $\mathrm{LH}$, resulting in an increase in sperm and $\mathrm{T}$ production by the testes (7-9).

A limited number of publications have demonstrated the efficacy of CC in the treatment of both male hypogonadism and male infertility $(1,10,11)$. Although the biochemical response of patients with male hypogonadism to CC has been reported, there is very little data regarding the subjective outcomes of men treated with CC for hypogonadism (4).
The aim of this study was to determine whether a daily dose of 25 milligrams of clomiphene citrate is effective in stimulating this endogenous $\mathrm{T}$ production pathway (through elevation of serum $\mathrm{T}$ levels) and in improving symptoms of hypogonadism (subjective response).

\section{MATERIALD AND METHODS}

Our cohort, from one center only, consisted of men with low sexual desire, low normal $\mathrm{T}$ (defined as serum total $\mathrm{T}$ between 300 and $400 \mathrm{ng} /$ $\mathrm{dL}$ ) or below normal $\mathrm{T}$ (defined as serum total $\mathrm{T}<$ $300 \mathrm{ng} / \mathrm{dL}$ ) and normal LH levels. Levels of serum total $\mathrm{T}$ were measured in morning blood samples by automated chemiluminescence immunoassay kit (Centaur ${ }^{\circledR}$, Siemens). If the patient complained of decrease of libido and presented low testosterone levels, he repeated T, LH, lipid profile, fasting glucose and prolactin. Men with above normal LH levels, indicating primary testicular failure, were not offered CC treatment. Men who presented with abnormal levels of PSA (PSA $\geq 2.5 \mathrm{ng} / \mathrm{mL}$ in men aged $\leq 55$ years or PSA $\geq 4 \mathrm{ng} / \mathrm{mL}$ in men aged $>55$ years) were also excluded. Other exclusion criteria were prior thromboembolic events, clinical suspicion of mammary neoplasia and/or patient's inability to provide informed consent. The decision to treat the patients with CC was left at the discretion of the urologist and patient choice after discussing treatment options. Any abnormal physical findings were reported.

Each patient was treated with a daily dose of $25 \mathrm{mg}$ clomiphene citrate and followed prospectively. At each evaluation (every 3 months) they had to answer a Global Assessment Question about the treatment (Did this treatment improve your symptoms based on sexual complaints? - libido and erections). All patients were on the medication for at least 3 months. Our mean follow-up was 6 months. If the patient had some $\mathrm{T}$ improvement at that time, they stayed under treatment indefinitely, but if there was no response, they stopped the drug. The same lab measurements were done each 3 months thereafter.

Statistical analysis was performed using SPSS $^{\circledR}$ with $\mathrm{P}$ values $<0.05$ considered statistically significant. Mean and standard deviation of 
the studied variables were also reported. Student's t test was used to compare pre and post treatment means of serum $\mathrm{T}$ and other variables. Patients were stratified according to their age in order to analyze treatment outcomes. Analysis of variance (ANOVA) was used to compare more than two means simultaneously. Chi square test was used to analyze subjective outcomes (Global Assessment Question: yes or no) according to the patient's age.

Ethical approval for the study was obtained in accordance with our local institutional requirements, and written informed consent was obtained from all subjects.

The main outcome measure in this paper is the change in $\mathrm{T}$ level after administration of clomiphene citrate to hypogonadal men. In this study, biochemical efficacy is defined as an elevation of serum $\mathrm{T}$ to the mid-normal range (above $500 \mathrm{ng} /$ $\mathrm{dL}$; normal range $206 \mathrm{ng} / \mathrm{dL}$ - $1200 \mathrm{ng} / \mathrm{dL}$, chemiluminescence immunoassay - Centaur ${ }^{\circledR}$, Siemens).

\section{RESULTS}

Our cohort consisted of 125 men with hypogonadism with low normal or below normal $\mathrm{T}$ and low or normal LH associated with a complaint of loss or decrease of the libido. Patients were prospectively enrolled from January 2008 to December 2009. Mean age was 62 years $( \pm$ 11.2 years). Serum T levels ranged from $310.27 \pm$ $95.96 \mathrm{ng} / \mathrm{dL}$ (baseline) to $669.03 \pm 239.68 \mathrm{ng} / \mathrm{dL}(3$ months after CC initiation) ( $\mathrm{p}<0.001$ ) (Figure-1). Mean serum cholesterol levels ranged from 197.50 $\pm 39.03 \mathrm{mg} / \mathrm{dL}$ (baseline) to $187.35 \pm 37.48 \mathrm{mg} / \mathrm{dL}$

Figure 1 - Serum testosterone levels (ng/dL) pre and post treatment with clomiphene citrate, 25mg/day, in 125 hypogonadal men (values expressed between 5 and 95 percentiles and the median).

Mean Increase in Serum Testosterone

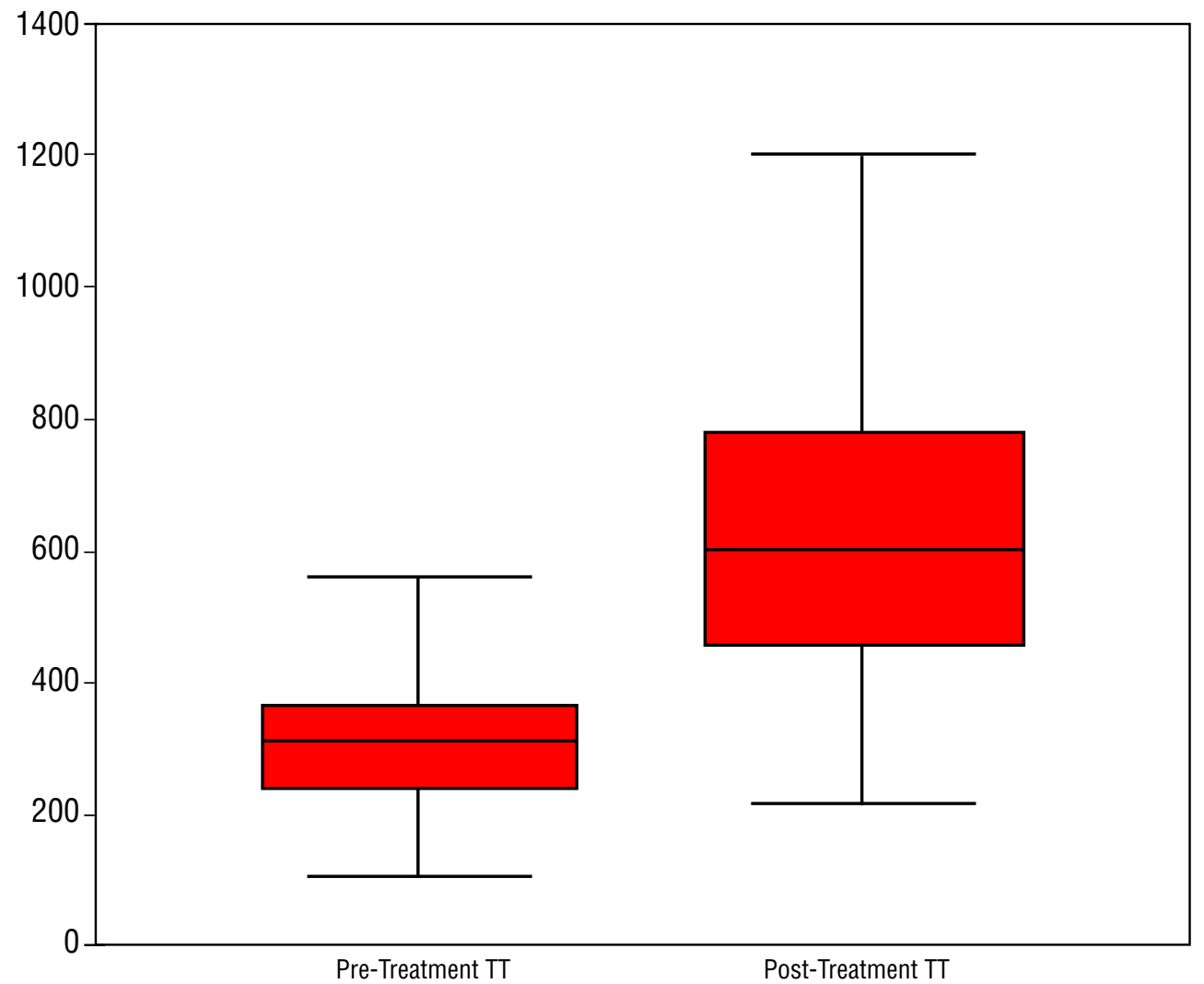


(3 months after CC initiation) $(\mathrm{p}=0.001)$. There were no statistically significant differences when comparing pre and post-treatment HDL-Cholesterol, triglycerides, fasting plasma glucose and prolactin (Table-1).

Sixty-eight percent of patients $(n=85)$ had a positive answer for the Global Assessment Question (Did this treatment improve your symptoms based on sexual complaints?). Mean increases in serum $\mathrm{T}$ were higher for patients who had a positive answer for the Global Assessment Question.
Objective and subjective responses depended mostly on patient's age. The younger the patient was, the greater was the increase in serum $\mathrm{T}$ (Table-2) and the chance for a positive QoL score. Mean increases in serum $\mathrm{T}$ were $465.4 \mathrm{ng} / \mathrm{dL}$, $351.9 \mathrm{ng} / \mathrm{dL}$ and $288.7 \mathrm{ng} / \mathrm{dL}$ for patients aged 30 to 50 years $(n=22), 51$ to 70 years $(n=77)$ and $\geq 71$ years $(n=26)$, respectively. Mean increase in serum $\mathrm{T}$ of younger patients (30 to 50 years) was statistically higher than mean increases of older patients (eg. 51 to 70 years, $p=0.04 ; \geq 71$ years, $p$ $=0.006$ ) (Figure-2).

Table 1 - Hormonal and biochemical parameters pre and post treatment with clomiphene citrate, 25 mg/day, in 125 hypogonadal men.

\begin{tabular}{lccc}
\hline Parameter & Pre-treatment ${ }^{*}$ & Post-treatment $^{*}$ & $P_{\text {value }}^{* \star}$ \\
\hline Serum Testosterone $(\mathrm{ng} / \mathrm{dL})$ & $310.27 \pm 95.95$ & $669.03 \pm 239.68$ & $<.0001$ \\
Total Cholesterol $(\mathrm{mg} / \mathrm{dL})$ & $197.50 \pm 39.03$ & $187.35 \pm 37.48$ & 0.001 \\
HDL Cholesterol $(\mathrm{mg} / \mathrm{dL})$ & $46.31 \pm 11.50$ & $45.62 \pm 11.92$ & 0.298 \\
Triglycerides $(\mathrm{mg} / \mathrm{dL})$ & $135.92 \pm 98.60$ & $129.08 \pm 82.77$ & 0.106 \\
Fasting glucose $(\mathrm{mg} / \mathrm{dL})$ & $101.44 \pm 18.67$ & $100 \pm 20.92$ & 0.359 \\
Prolactin $(\mu \mathrm{g} / \mathrm{L})$ & $9.68 \pm 5.04$ & $9.52 \pm 6.27$ & 0.711 \\
\hline
\end{tabular}

*mean \pm standard deviation

**Paired samples T Test

Table 2 - Serum Testosterone Outcomes According To Patient's Age.

\begin{tabular}{lcccc}
\hline $\begin{array}{l}\text { Age } \\
\text { (years) }\end{array}$ & $\mathrm{N}$ & $\begin{array}{c}\text { Pre-treatment Serum Testosterone } \\
\mathrm{ng} / \mathrm{dL}\end{array}$ & $\begin{array}{c}\text { Post-treatment Serum Testosterone }^{*} \\
\mathrm{ng} / \mathrm{dL}\end{array}$ & P value $^{* *}$ \\
\hline $30-50$ & 22 & $329.18 \pm 87.76$ & $794.59 \pm 231.05$ & - \\
$51-70$ & 77 & $296.41 \pm 85.53$ & $648.35 \pm 238.13$ & 0.026 \\
$\geq 71$ & 26 & $335.30 \pm 124.08$ & $624.03 \pm 224.53$ & 0.032 \\
\hline
\end{tabular}

${ }^{*}$ mean \pm standard deviation

** Turkey's test for post hoc analysis of ANOVA 
Figure 2 - Increase in Serum Testosterone (3 months after initiation of 25 mg CC) versus Age Groups and Global Assessment Question.

Mean Increase in Serum Testosterone

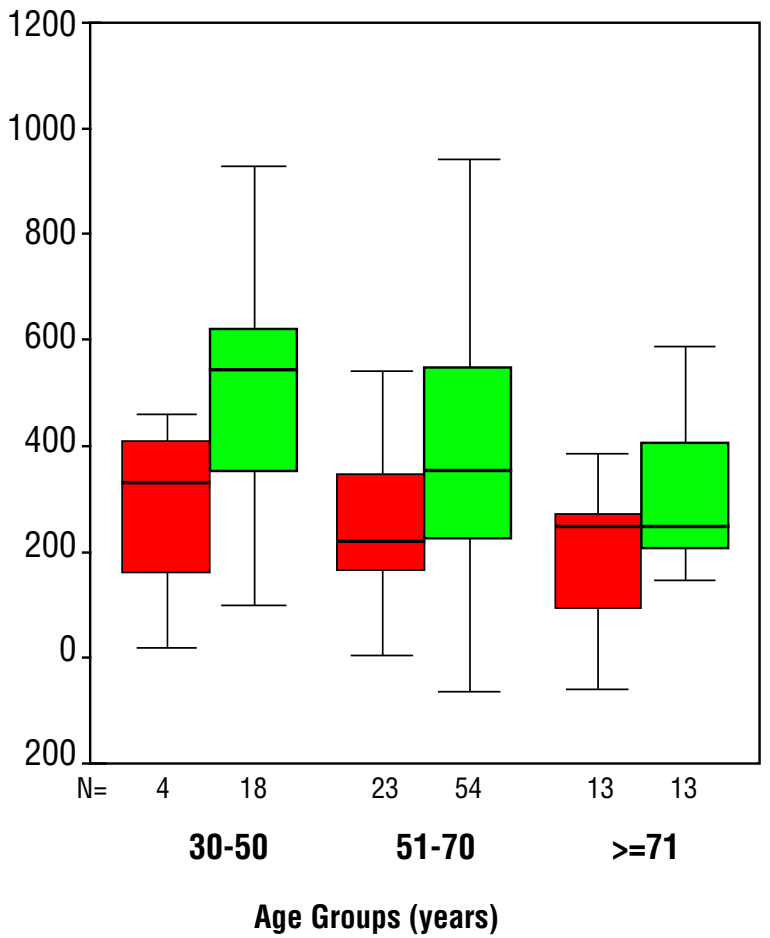

Global Assessment Question: Did this treatment improve yours symptoms based on sexual complaints?

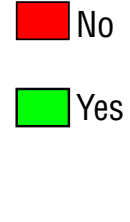

$$
\begin{aligned}
& p=0.017^{*} \\
& \text { * chi square test }
\end{aligned}
$$

No serious adverse events were recorded during the study period. Six patients (5\%) complained of nipple tenderness. This complaint persisted all over the treatment for some patients and for others disappeared spontaneously.

\section{DISCUSSION}

The world population is increasing and becoming aged. Nowadays there are no more doubts that old men have a decrease of their serum levels of testosterone. Hypogonadism in aging males results in a steady decline in testosterone levels at a rate of 1\% per year after age 40 years (12). There is an inverse relationship between the low serum testosterone levels and the presence of sexual complaints. It is important to reinforce that the diagnosis of hypogonadism depends on the laboratorial data (subnormal or low normal testosterone) and the clinical symptoms (13).

We actually believe that more than 20\% of the patients older than 60 years present signs and symptoms of hypogonadism. Wu et al. recently found $17 \%$ of symptomatic hypogonadism (total testosterone less than $320 \mathrm{ng} / \mathrm{dL}$ ) in a population of 3369 men between the ages of 40 and 79 years (14). These hypogonadic patients have complaints about mood, memory, impaired physical activities, weakness, diminished libido and erectile dysfunction $(15,16)$.

Testosterone therapy has been indicated for the treatment of loss of libido and erectile dysfunction in hypogonadal men. The goal of testosterone therapy is to maintain physiological levels of this hormone. A rough quantization of the minimum amount of total testosterone 
necessary for nocturnal erections indicated that $200 \mathrm{ng} / \mathrm{dL}$ of total testosterone was adequate for maximal response (17). The ISSAM (International Society for the Study of Aging Male) suggests that values of total $\mathrm{T}$ below $200 \mathrm{ng} / \mathrm{dL}$ represent hypogonadism and should be treated (15) and men with $\mathrm{T}$ level between $200 \mathrm{ng} / \mathrm{dL}$ and $400 \mathrm{ng} / \mathrm{dL}$ could experience a therapeutic trial of $\mathrm{T}$ supplement. Despite of the fact that $T$ therapy does not mimic the normal circadian hormone secretion, it is generally successful.

Clomiphene citrate (CC) is an orally administered, nonsteroidal ovulatory drug typically used in female infertility management. This drug has estrogenic and antiestrogenic properties and increases the steroidogenesis (18). CC has been shown to increase $\mathrm{T}$ levels in both normal and impotent hypogonadal men probably reflecting the primacy of estrogen over $\mathrm{T}$ in the feedback regulation of male gonadal function. In a small, double blind, placebo-controlled, crossover study of clomiphene against placebo in impotent men with secondary hypogonadism, Guay et al. observed a significant rise of $\mathrm{T}$ with clomiphene (19). Tenover et al. also found an improvement in serum levels of $\mathrm{T}$ in a group of ten men using chronic CC (6). The appeal of CC in the treatment of functional hypogonadotropic hypogonadism in males lies in the re-establishment of physiologic hypothalamic-pituitary-gonadal feedback regulation and function (20). Guay et al. had good results over libido and erections when their 173 patients used 50mg 3 times a week. Seventy five percent had improvement in erectile function and $39 \%$ returned to normal sexual function (21). Nevertheless, correcting the testosterone deficit may have other beneficial effects. These may include increasing energy and well-being, as well as prevention of anemia or bone loss, depending on the severity of the hypogonadism. If patients cannot maintain their testosterone levels in the normal range after clomiphene is discontinued, permanent testosterone replacement with intramuscular injection, transdermal patches or gels should be considered (21).

In our trial, we used a low oral daily dose of clomiphene citrate $(25 \mathrm{mg})$ in 125 men with a mean age of 62 years. All patients had low nor- mal or below normal $\mathrm{T}$ levels and all of them complained about decrease or loss of libido. They were enrolled and followed prospectively. Post-treatment T levels increased by a mean of 115\%. Both objective and subjective responses were more impressive in younger patients. Considering that clomiphene acts on central axis, ultimately stimulating the production of testosterone by the testicles, young men could be benefited more than elderly, theoretically by having a major testicular cells reserve.

In this study, we did not use a validated QoL questionnaire. This represents a limitation. However, the global assessment question could provide some information on the subjective response to the treatment. Moreover, our mean follow-up was only 6 months (short-term follow-up). Further studies are needed to assess long-term results in regards to the use of clomiphene citrate on the treatment of male testosterone deficiency.

\section{CONCLUSIONS}

Our data showed that a daily dose of $25 \mathrm{mg}$ clomiphene citrate was effective in stimulating endogenous $\mathrm{T}$ production in a short follow-up. On the other hand, lower levels of total cholesterol were verified after 3 months of treatment. Both objective and subjective responses to CC depended mostly on patient's age: the younger the patient was, the greater was the increase in serum $\mathrm{T}$ and the chance for a positive QoL score. No serious adverse events were recorded during the study period. This medication should be considered a therapeutic option for patients with symptomatic male testosterone deficiency.

\section{CONFLICT OF INTEREST}

None declared.

\section{REFERENCES}

1. Shabsigh A, Kang Y, Shabsign R, Gonzalez M, Liberson G, Fisch $\mathrm{H}$, et al.: Clomiphene citrate effects on testosterone/ estrogen ratio in male hypogonadism. J Sex Med. 2005; 2: 716-21. 
2. Travison TG, Morley JE, Araujo AB, O'Donnell AB, McKinlay $\mathrm{JB}$ : The relationship between libido and testosterone levels in aging men. J Clin Endocrinol Metab. 2006; 91: 2509-13.

3. Neaves WB, Johnson L, Porter JC, Parker CR Jr, Petty CS: Leydig cell numbers, daily sperm production, and serum gonadotropin levels in aging men. J Clin Endocrinol Metab. 1984; 59: 756-63.

4. Taylor F, Levine L: Clomiphene citrate and testosterone gel replacement therapy for male hypogonadism: efficacy and treatment cost. J Sex Med. 2010; 7(1 Pt 1): 269-76.

5. Hermann M, Untergasser G, Rumpold H, Berger P: Aging of the male reproductive system. Exp Gerontol. 2000; 35 : 1267-79.

6. Morales A, Heaton JP, Carson CC 3rd: Andropause: a misnomer for a true clinical entity. J Urol. 2000; 163: 705-12.

7. Ioannidou-Kadis S, Wright PJ, Neely RD, Quinton R: Complete reversal of adult-onset isolated hypogonadotropic hypogonadism with clomiphene citrate. Fertil Steril. 2006; 86: 1513.e5-9.

8. Goldstein SR, Siddhanti S, Ciaccia AV, Plouffe L Jr.: A pharmacological review of selective oestrogen receptor modulators. Hum Reprod Update. 2000; 6: 212-24.

9. Tenover JS, Bremner WJ: The effects of normal aging on the response of the pituitary-gonadal axis to chronic clomiphene administration in men. J Androl. 1991; 12: 258-63.

10. Hussein A, Ozgok Y, Ross L, Niederberger C: Clomiphene administration for cases of nonobstructive azoospermia: a multicenter study. J Androl. 2005; 26: 787-91; discussion 792-3.

11. Whitten SJ, Nangia AK, Kolettis PN: Select patients with hypogonadotropic hypogonadism may respond to treatment with clomiphene citrate. Fertil Steril. 2006; 86: 1664-8.

12. Harman SM, Metter EJ, Tobin JD, Pearson J, Blackman MR; Baltimore Longitudinal Study of Aging: Longitudinal effects of aging on serum total and free testosterone levels in healthy men. Baltimore Longitudinal Study of Aging. J Clin Endocrinol Metab. 2001; 86: 724-31.

13. Black AM, Day AG, Morales A: The reliability of clinical and biochemical assessment in symptomatic late-onset hypogonadism: can a case be made for a 3-month therapeutic trial? BJU Int. 2004; 94: 1066-70.
14. Wu FC, Tajar A, Beynon JM, Pye SR, Silman AJ, Finn JD, et al.: Identification of late-onset hypogonadism in middleaged and elderly men. N Engl J Med. 2010; 363: 123-35.

15. Wang C, Nieschlag E, Swerdloff R, Behre HM, Hellstrom WJ, Gooren LJ, et al.: Investigation, treatment and monitoring of late-onset hypogonadism in males: ISA, ISSAM, EAU, EAA and ASA recommendations. Eur J Endocrinol. 2008; 159: 507-14.

16. Bhasin S, Cunningham GR, Hayes FJ, Matsumoto AM, Snyder PJ, Swerdloff RS, et al.: Testosterone therapy in adult men with androgen deficiency syndromes: an endocrine society clinical practice guideline. J Clin Endocrinol Metab. 2006; 91: 1995-2010. Erratum in: J Clin Endocrinol Metab. 2006; 91: 2688

17. Granata AR, Rochira V, Lerchl A, Marrama P, Carani C: Relationship between sleep-related erections and testosterone levels in men. J Androl. 1997; 18: 522-7.

18. Tan RS, Vasudevan D: Use of clomiphene citrate to reverse premature andropause secondary to steroid abuse. Fertil Steril. 2003; 79: 203-5.

19. Guay AT, Bansal S, Heatley GJ: Effect of raising endogenous testosterone levels in impotent men with secondary hypogonadism: double blind placebo-controlled trial with clomiphene citrate. J Clin Endocrinol Metab. 1995; 80: 3546-52.

20. Burge MR, Lanzi RA, Skarda ST, Eaton RP: Idiopathic hypogonadotropic hypogonadism in a male runner is reversed by clomiphene citrate. Fertil Steril. 1997; 67: 783-5.

21. Guay AT, Jacobson J, Perez JB, Hodge MB, Velasquez E: Clomiphene increases free testosterone levels in men with both secondary hypogonadism and erectile dysfunction: who does and does not benefit? Int J Impot Res. 2003; 15: $156-65$.

Correspondence address:

Dr. Carlos Teodósio Da Ros Rua Soledade 569 / 907B, Bairro Três Figueiras Fax: +55 51 3378-9996

Porto Alegre, RS, 90470-340

E-mail: daroscarlos@yahoo.com 